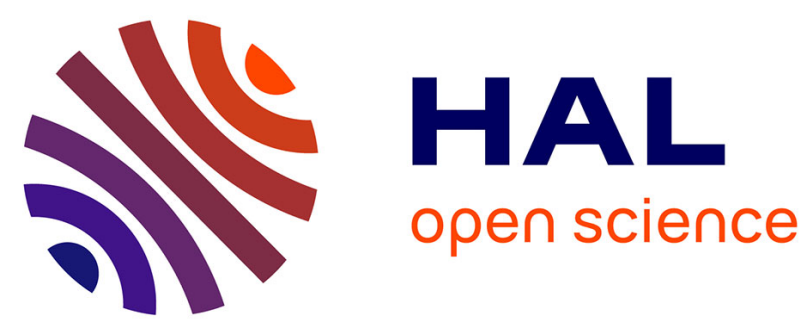

\title{
Retrospective survey on the off-label use of posaconazole in pediatric hematology patients
}

S. Cesaro, G. M. Milano, F. Aversa

\section{To cite this version:}

S. Cesaro, G. M. Milano, F. Aversa. Retrospective survey on the off-label use of posaconazole in pediatric hematology patients. European Journal of Clinical Microbiology and Infectious Diseases, 2010, 30 (4), pp.595-596. 10.1007/s10096-010-1123-8 . hal-00646928

\section{HAL Id: hal-00646928 \\ https://hal.science/hal-00646928}

Submitted on 1 Dec 2011

HAL is a multi-disciplinary open access archive for the deposit and dissemination of scientific research documents, whether they are published or not. The documents may come from teaching and research institutions in France or abroad, or from public or private research centers.
L'archive ouverte pluridisciplinaire HAL, est destinée au dépôt et à la diffusion de documents scientifiques de niveau recherche, publiés ou non, émanant des établissements d'enseignement et de recherche français ou étrangers, des laboratoires publics ou privés. 
Simone Cesaro ${ }^{1 *}$, Giuseppe Maria Milano, Franco Aversa.

${ }^{1}$ Pediatric Hematology Oncology, Department of Pediatrics, University of Padova, Italy

${ }^{2}$ Pediatric Hematology, Ospedale Santa Maria della Misericordia, Azienda Ospedaliera, Perugia, Italy

* Current affiliation:

Pediatric Hematology Oncology, Azienda Ospedaliera Universitaria Integrata, Verona, Italy

Number of text words: 536

Number of references : 3

Running title: Posaconazole in children

Keywords: invasive mycosis, aspergillosis, pediatrics, posaconazole

\section{Corresponding author:}

Simone Cesaro, M.D.

Pediatric Hematology Oncology

Policlinico G.B. Rossi, Azienda Ospedaliera Universitaria Integrata

Piazzale LA Scuro 10

37134, Verona

Italy

Phone: 0039-045-812.6889 (secretary)-4931 (office)

Fax: +39-045-8124889

e-mail: simone.cesaro@ospedaleuniverona.it 
Sir,

Lehrnbecher et al. recently reported the off-label use of posaconazole in 15 pediatric hematology patients affected by invasive fungal infections. They concluded that posaconazole is safe and welltolerated in pediatric patients, although pharmacokinetic studies are needed to optimize its use in this age group [1]. We assessed retrospectively the patients treated off-label at our centers with posaconazole from 1 March 2008 to 30 May 2009. Over a 15-month period we collected 15 patients, median age of 10 years, range 3-17, affected by acute lymphoblastic leukemia (5), acute myeloid leukemia/myelodysplasia (7), severe aplastic anemia (1), hemophagocytic lymphohystiocytosis (1), Ewing's sarcoma (1), who received posaconazole. Nine of the patients had undergone allogeneic stem cell transplantation (SCT) with different stem cell donor sources: 2 haploidentical donor, 3 cord blood, 3 unrelated donor, 1 sibling donor, while 6 were neutropenic patients on treatment for acute myeloid leukemia/myelodysplasia. Lung involvement was present in 12 patients and classified as proven aspergillosis in 1 patient, probable aspergillosis in 10 patients, and possible mycosis in 1 patient; the remaining 3 patients received posaconazole as primary ( 2 patients) or secondary (1 patient) prophylaxis for high-risk situations such as acute graft versus host disease treated with steroids ( 2 patients), and haploidentical SCT (1 patient). The dose used was $3 \mathrm{x}$ $200 \mathrm{mg} /$ day in 12 patients, $2 \times 400 \mathrm{mg} /$ day in 2 patients, and $3 \times 100 \mathrm{mg} /$ day in 1 patient. No therapeutic drug monitoring was performed. For the 12 patients with lung infections, 9 were treated with posaconazole as rescue therapy after 1 course ( 1 patient), 2 courses ( 5 patients) or 3 courses ( 3 patients) of antifungal therapy while 3 patients received posaconazole as secondary prophylaxis. The antifungal drugs used alone or in combination before starting posaconazole were: liposomal amphotericin B in 11 patients, voriconazole in 6 patients, caspofungin in 4 patients. As at August 30,2009 , these patients had been treated with posaconazole for a median of 273 days, range 150665 days. The assessment of efficacy after 90 days of posaconazole showed a significant clinicalradiological improvement in 9 patients. After a median follow-up of 12 months from the beginning 
of infection, 11 of 12 patients were alive with a complete response in 9 and a partial response in 2. One patient with Ewing's sarcoma died during treatment due to progression of the disease but in complete response from posaconazole. None of the 3 patients treated as primary or secondary prophylaxis developed or had a relapse of mycoses. These patients were treated for 124,158 and 332 days respectively. Posaconazole was well-tolerated and no patient was withdrawn from treatment for adverse events related to its use. Posaconazole is a broad spectrum triazole licensed for adult patients as antifungal prophylaxis in acute myeloid leukemia, myelodysplastic syndrome, allogeneic transplant patients during treatment for acute graft versus host disease $e_{s}$ and as salvage treatment for aspergillosis and other mould infections [2]. Pharmacokinetic data for pediatric patients are limited as well as data on efficacy $[1,3]$. Given the paucity of data available so far, we submit this further evidence that posaconazole may represent an alternative choice for the therapy and prophylaxis of fungal infections in pediatric patients, although we recognize that more studies are needed to optimize the posaconazole dosage.

\section{References}

1) Lehrnbecher T, Attarbashi A, Duerken M, Garbino J, Gruhn B, Kontny U, Luer S, Phillips R, Scholz, Wagner HJ, Wiesel T, Groll AH (2010) Posaconazole salvage treatment in paediatric patients: a multicentre survey. Eur J Clin Microbiol Infect Dis 29:1045-5

2) Groll AH, Tragiannidis A (2010) Update on antifungal agents for paediatric patients. Clin Microbiol Infect 16:1343-1353

3) Krishna G, Sansone-Parsons A, Martinho M, Kantesaria B, Pedicone L (2007) Posaconazole plasma concentrations in juvenile patients with invasive fungal infection. Antimicrob Agents Chemother 51:812-8 